\title{
Dietary Management of Diabetes: Focus on Ketogenic Diet
}

\author{
Rajiv Singla ${ }^{1}$ Rahul Rosha ${ }^{2}$ Sanjay Kalra ${ }^{3}$ \\ ${ }^{1}$ Department of Endocrinology, Kalpavriksh Healthcare, New Delhi, India \\ ${ }^{2}$ Department of Nutrition, Novique Healthcare, Pune, Maharashtra, India \\ ${ }^{3}$ Department of Endocrinology, Bharti Hospital, Karnal, Haryana, India
}

\author{
Address for correspondence Sanjay Kalra, MD, DM, Department of \\ Endocrinology, Bharti Hospital, Karnal 132001, Haryana, India \\ (e-mail: brideknl@gmail.com).
}

\begin{abstract}
Keywords

- ketogenic diet

- evolution

- diet in diabetes

In an era of ever-increasing burden of obesity and diabetes, an out-of-the-box thinking is required to challenge the status quo. With dismal results of current nutritional and therapeutic armamentarium, ketogenic diet can provide this opportunity. Ketogenic diet has profound pathophysiological as well as evolutionary basis for it to be used as a tool in diabetes management. Despite progressively accumulating evidence for clinical efficacy and safety, widespread adoption of ketogenic diet remains low due to lack of expertise and standard guidelines.
\end{abstract}

\section{Introduction}

Importance of lifestyle changes, including diet and exercise, has always been undermined in the management of diabetes, especially in the western literature. The main reason, often cited, is nonsustainability of these measures. There has been recent evolution in the literature to challenge this notion. A new approach and a fresh look into the role of lifestyle change in diabetes care is needed in view of suboptimal response to current care standards. Even in the best-case scenario, average hemoglobin A1c (HbA1c) in India among people with diabetes vary between 8.1 and $9.5 \%$, which is far from optimal levels. ${ }^{1}$ This assumes even more significance in view of much earlier onset of diabetes and increasing life expectancy in India.

\section{Spectrum of Diet}

Diets in diabetes care vary in different geographies of world and have been listed in - Table 1 .

\section{Calorie Restriction}

Most common diet that is followed worldwide is the so-called balanced diet with 50 to $70 \%$ carbohydrate, $20 \%$ proteins, and rest fats. ${ }^{2}$ It has been endorsed by institutions such as American Diabetes Association and National Institute of Nutrition, India. ${ }^{3}$ To be effective in the management of diabetes and obesity, it has to be low in calorie. In a recent study, diet with this macronutrient proportions given with very low caloric value, has been shown to be very effective. ${ }^{7}$ A total of 306 individuals between 20 and 65 years of age, duration of diabetes less than 6 years, and with body mass index of 27 to $45 \mathrm{~kg} / \mathrm{m}^{2}$ were recruited from National Health Service centers in England and Scotland. Participants were started on meal replacements with approximately $850 \mathrm{Kcal} /$ day and were subjected to stepped food reintroduction. At the end of 1 year of intervention, $46 \%$ of the participants achieved diabetes remission, defined as HbA1c $<6.5 \%$ for at least 2 months without any antidiabetic medication. This remission was strongly correlated with weight loss. Participants who lost $15 \mathrm{~kg}, 86 \%$ of them achieved remission. This study is a significant step toward establishing diet intervention as a potent tool in the management of diabetes. It has already been advocated that diet interventions should have a definite role in the algorithm of diabetes care at par with drugs. ${ }^{8}$ However, sustainability of high carb, low calorie diet has always been an issue and its biological basis for the same are proposed in - Fig. 1 .

\section{Carbohydrate Restriction: Ketogenic Diet}

\section{Evolutionary Endocrinology}

Ketogenic diet may turn out be pathophysiologically the most sound way of treating people with diabetes. Fundamentally, diabetes is the inability of the human body to take carbohydrate metabolism to its conclusion. This results in the accumulation of glucose in blood and starvation at the muscle 
Table 1 Macronutrient distribution (as percentage of total daily calories) in different diets

\begin{tabular}{|l|l|l|l|}
\hline & Carbohydrates (\%) & Proteins (\%) & Fats (\%) \\
\hline SAD $^{2}$ & $50-60$ & $10-20$ & $25-35$ \\
\hline NIN $^{3}$ & $70-80$ & $10-20$ & $10-20$ \\
\hline Mediterranean & & $30-35$ \\
\hline Paleolithic $^{5}$ & $30-40$ & $20-30$ & $35-45$ \\
\hline Ketogenic Diet & $20-30$ & $25-35$ & $65-70$ \\
\hline
\end{tabular}

Abbreviations: NIN, National Institute of Nutrition; SAD, standard American diet.

level due to the inability to metabolize it due to resistance to action of insulin. Diabetes can be forced into remission if we change the fuel type from carbohydrate to fats. Human body has enough molecular mechanisms to switch between the fuels. In fact, carbohydrates are the only nutrient in diet for which no safe lower limit has ever been defined. ${ }^{9}$

\section{Ketogenic Age}

Over the periods of evolution, adapting to a particular fuel type has been advantageous. Right from the eternity till some 8,000 years back, every human being was on ketogenic diet. People used to hunt and gather and eat food whenever it was

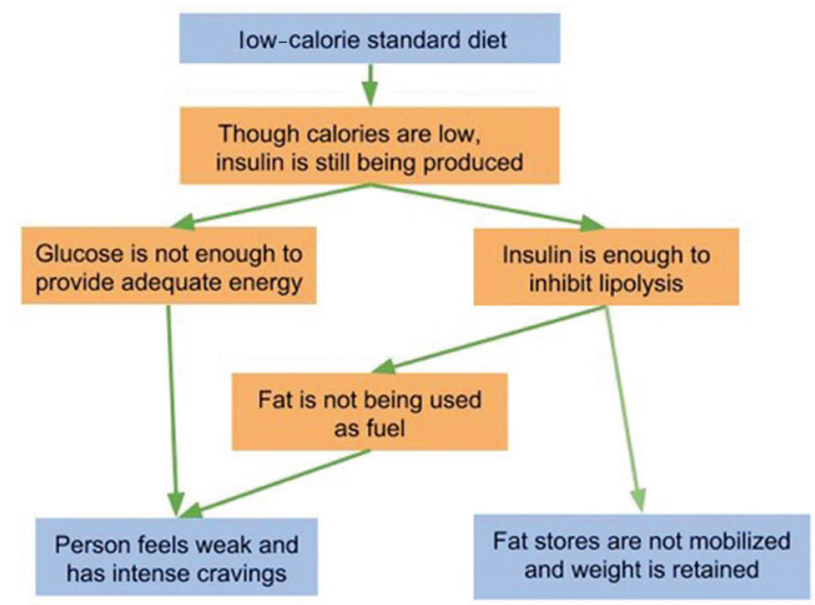

Fig. 1 Biological basis of failure and nonsustainability of low calorie diet. available. ${ }^{10}$ There was general scarcity of food, and human beings were somewhere in the middle of the food chain. During lean months with harsh weather, humans would perish of malnutrition ( - Fig. 2).

\section{Eumetabolic Carbohydrate Age}

As humans started cultivation and included more grains in their food, it gave them a distinctive survival advantage. It protected them in two ways. First, increased carb intake allowed their insulin levels to go up and this, in turn, allowed their bodies to store energy in the form of increased fat generation (lipogenesis) and fat storage. Second, cultivation allowed them to stay together and at one place; thus, avoiding other predators on the move ( - Fig. $\mathbf{3}$ ).

Cultivation, led by its biological, social, and environmental advantages, changed the course of human history, and humans thrived to reach on top of the food chain on this planet. Taking more carbohydrates became ingrained in almost all civilizations worldwide. This biological switch (from fat as a fuel to carbohydrate as a fuel) continued to serve a useful purpose till food availability was limited. This all changed with herald of the industrial era.

\section{Maladaptive Carbohydrate Age}

After the industrial revolution, in early 20th century, food scarcity had not been a problem. We are now living in a world with surplus food. But the same advantageous biological switch (from fat as a fuel to carbohydrate as a fuel) that was developed over thousands of year cannot really be switched off in few decades. People held on to their traditions and carbohydrates stayed as their staple food. But now it is working to our disadvantage ( - Fig. 4).
Food rich in protein and fat (from hunting) and with very little carbs (coming from gathered fruits)

Fig. 2 Energy metabolism in the preagricultural ketogenic era.
Low capacity to store energy

\section{Survival Disadvantage}

Increased adipogenesis and fat storage. Carbs replaced fats as primary fuel
Survival advantage as stored fat could be used as fuel during harsh conditions

Fig. 3 Insulin offered survival advantage in the agricultural era. 


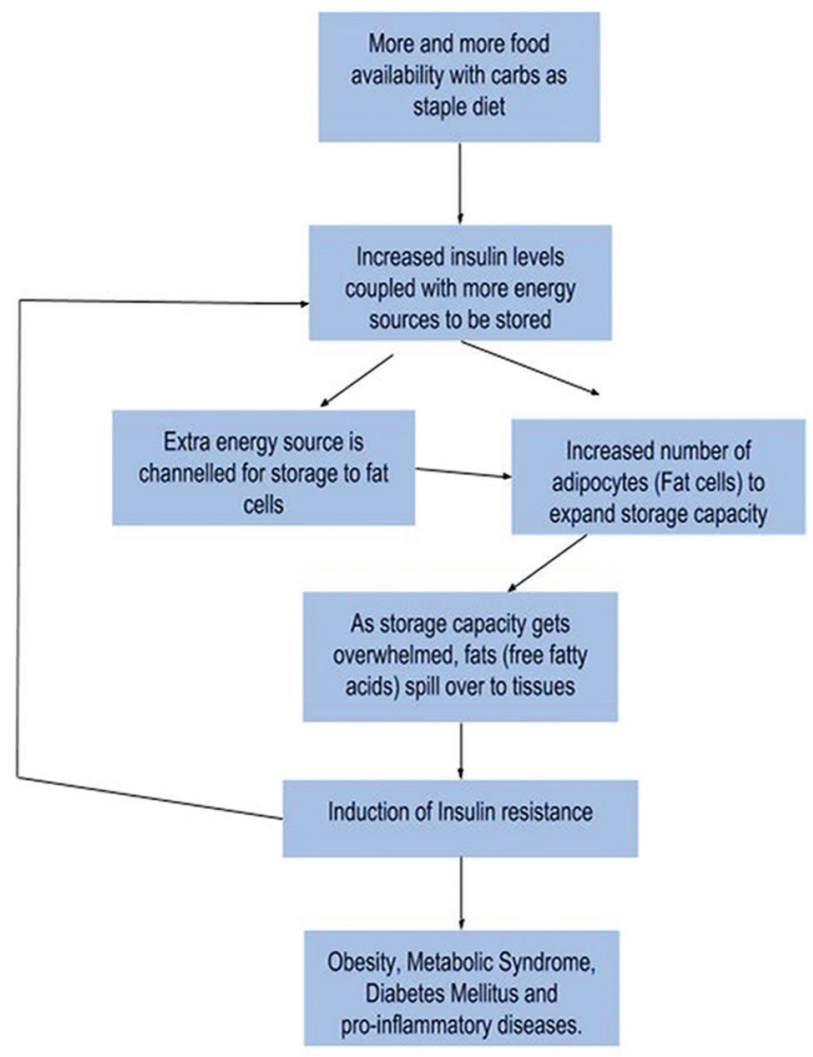

Fig. 4 Maladaptive carbohydrate metabolism in modern era.

\section{Pragmatism for the Future}

Actually, from this point of view, we do not need insulin anymore as a survival tool. Insulin would still be required as an essential ingredient of metabolic milieu of the human body. But taking more carbohydrates and making more insulin inside our bodies is not helping us anymore. Of course, evolution is going to take its own time to turn this biological switch off. There are two ways to handle this now. One, we can make food scarce for everybody and turn the clock back to the preindustrial era. This sounds a little too harsh and illogical. But, looking around, that is exactly what we have been doing so far by restricting calories that people eat.

Second option to turn off that switch is by cutting down on carbohydrates that we take in our diets. Lowering insulin lowers the energy overload in the system and reverses all metabolic abnormalities (-Fig. 5).

\section{Evidence Base}

Slowly, but steadily, the literature documenting the efficacy of ketogenic diet in the management of diabetes has been gathering. Very low carbohydrate ketogenic diets have consistently showed greater reduction in Hba1c as well as in weight. Few notable studies have been compiled in - Table 2 .

In a recent study, 262 participants with 8 years duration of diabetes and a baseline HbA1c of 7.6\% were given very low carbohydrate ketogenic diet. ${ }^{17}$ Eighty-four percent participants complied with the program at the end of 1 year. HbA1c decreased from 7.6 to $6.29 \%$ and that too with large reduction

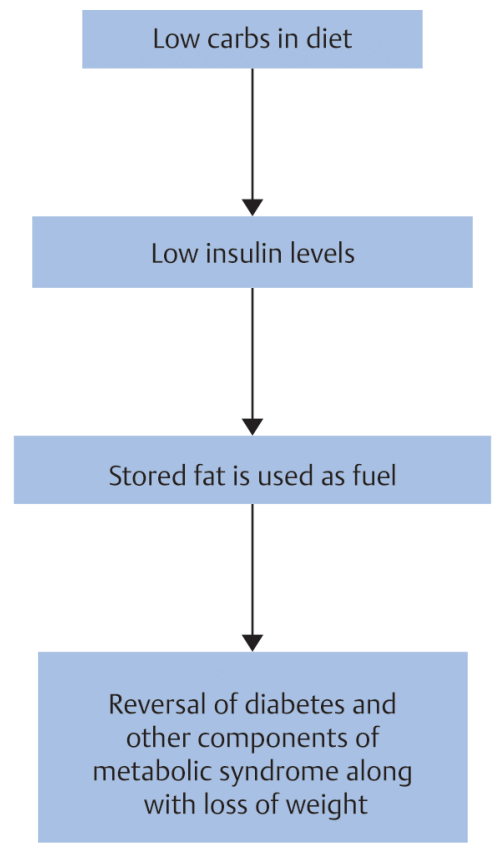

Fig. 5 Lowering the carbohydrate may hold the key.

in the requirement of antidiabetic drugs. Insulin was eliminated in $47.6 \%$ of patients, sulfonylureas were eliminated in $100 \%$ of patients, and other drugs, including SGLT2 inhibitors, DPP4 inhibitors, and pioglitazone, were eliminated in large proportion of patients. There was also a reported weight loss of $13.6 \%$ at the end of 1 year. ${ }^{17} \mathrm{~A}$ subsequent publication also reported almost $12 \%$ risk reduction in 10 years atherosclerotic cardiovascular disease risk in same the cohort of people. ${ }^{18}$

Even in the general population (without diabetes), decrease in carbohydrate intake has been shown to be associated with lower all-cause and noncardiovascular mortality while cardiovascular mortality was unaffected.

\section{Caveats and Concerns}

While ketogenic diet seems to be a very attractive alternative for diabetes care, lack of availability of expertise especially in the Indian subcontinent is a matter of concern. Common issues faced include low energy levels during the initial 2 weeks representing the transition phase for fuel switch from carbohydrates to fats. As most of the treatment algorithms for drug usage in diabetes management are based on presumptive intake of carbohydrate predominant diet, protocols for using the same drugs on ketogenic diet are practically nonexistent in the literature. In the long term, proper supplementation of micronutrients is warranted.

\section{Conclusion}

Ketogenic diet is emerging as a powerful lifestyle tool in the treatment of diabetes. Ketogenic diet seems to have very strong pathophysiological basis to be used as a therapeutic 
Table 2 Compilation of studies on ketogenic diet for the treatment of diabetes

\begin{tabular}{|c|c|c|c|c|c|}
\hline $\begin{array}{l}\text { Serial } \\
\text { no. }\end{array}$ & $\begin{array}{l}\text { Author, } \\
\text { country, } \\
\text { journal, } \\
\text { year of } \\
\text { publication }\end{array}$ & $\begin{array}{l}\text { No. of } \\
\text { patients }\end{array}$ & Intervention & Results & Adverse effects \\
\hline 1 & $\begin{array}{l}\text { Yancy et } \\
\text { al, United } \\
\text { States, Nu- } \\
\text { trition and } \\
\text { Metabolism, } \\
2005^{11}\end{array}$ & 21 & $\begin{array}{l}\text { Low car- } \\
\text { bohydrate } \\
\text { ketogenic } \\
\text { diet (LCKD) } \\
\text { for } 16 \text { wk }\end{array}$ & $\begin{array}{l}\text { Hemoglobin } A_{1 c} \text { decreased from } 7.5 \\
\pm 1.4 \% \text { to } 6.3 \pm 1.0 \%(p<0.001) . \text { The } \\
\text { mean body weight decreased by } 6.6 \% \\
\text { from } 131.4 \pm 18.3 \text { to } 122.7 \pm 18.9 \mathrm{~kg} \\
(p<0.001)\end{array}$ & $\begin{array}{l}\text { No serious adverse effects } \\
\text { reports. One episode of hypo- } \\
\text { glycemia after missing meal }\end{array}$ \\
\hline 2 & $\begin{array}{l}\text { Westman et } \\
\text { al, United } \\
\text { States, Nu- } \\
\text { trition and } \\
\text { Metabolism, } \\
2008^{12}\end{array}$ & 49 & $\begin{array}{l}\text { LCKD versus } \\
\text { low calorie } \\
\text { diet }(L C D)\end{array}$ & $\begin{array}{l}\text { The LCKD group had greater improve- } \\
\text { ments in hemoglobin A1c }(-1.5 \% \\
\text { vs. }-0.5 \%, p=0.03) \text {, body weight } \\
(-11.1 \mathrm{~kg} \text { vs. }-6.9 \mathrm{~kg}, p=0.008) \text {. } \\
\text { Diabetes medications were reduced } \\
\text { or eliminated in } 95.2 \% \text { of LCKD versus } \\
62 \% \text { of low-glycemic index diet (LGID) } \\
\text { participants }(p<0.01)\end{array}$ & $\begin{array}{l}\text { Headache (LCKD: 53.1\%, LGID: } \\
\text { 46.3\%), constipation (LCKD: } \\
\text { 53.1\%, LGID: 39.0\%), diarrhea } \\
\text { (LCKD: 40.6\%, LGID: 36.6\%), } \\
\text { insomnia (LCKD: } 31.2 \%, \text { LGID: } \\
\text { 19.5\%), and back pain (LCKD: } \\
\text { 34.4\%, LGID: } 39.0 \% \text { ) ( } p>0.05 \\
\text { for all comparisons) }\end{array}$ \\
\hline 3 & $\begin{array}{l}\text { Davis et } \\
\text { al, United } \\
\text { States, Dia- } \\
\text { betes Care, } \\
2009^{13}\end{array}$ & 110 & $\begin{array}{l}\text { Low carb } \\
\text { versus low } \\
\text { fat diet for } \\
12 \text { mo }\end{array}$ & $\begin{array}{l}\text { Weight loss occurred faster in the low- } \\
\text { carbohydrate group than in the low-fat } \\
\text { group }(p=0.005) \text {, but at } 1 \mathrm{y} \text { a similar } \\
3.4 \% \text { weight reduction was seen in both } \\
\text { dietary groups. There was no significant } \\
\text { change in } \mathrm{A} 1 \mathrm{C} \text { in either group at } 1 \mathrm{y}\end{array}$ & None reported \\
\hline 4 & $\begin{array}{l}\text { Saslow et } \\
\text { al, United } \\
\text { States, JMIR, } \\
2017^{14}\end{array}$ & 25 & $\begin{array}{l}\text { LCKD versus } \\
\text { American } \\
\text { Diabetes } \\
\text { Association } \\
\text { (ADA) Plate } \\
\text { method diet } \\
\text { for } 32 \text { wk; } \\
\text { online }\end{array}$ & $\begin{array}{l}\text { At } 32 \text { wk, participants in the interven- } \\
\text { tion group reduced their } \mathrm{HbA}_{1 \mathrm{c}} \text { levels } \\
\text { more }(-0.8 \%) \text { than participants in the } \\
\text { control group }(-0.3 \%) \text {. Participants in } \\
\text { the intervention group lost more weight }\end{array}$ & No SAR reported \\
\hline 5 & $\begin{array}{l}\text { Hussain et } \\
\text { al, Kuwait, } \\
\text { Nutrition, } \\
2012^{15}\end{array}$ & $\begin{array}{l}363 \\
\text { overall, } \\
102 \text { with } \\
\text { diabetes } \\
\text { mellitus } \\
\text { type } 2 \\
\text { (DM2) }\end{array}$ & $\begin{array}{l}\text { LCKD versus } \\
\text { LCD for } 24 w k\end{array}$ & $\begin{array}{l}12 \% \text { weight loss in LCKD versus } 7 \% \text { in } \\
\text { LCD. HbA1c level significantly decreased } \\
\text { with the low-carbohydrate ketogenic } \\
\text { diet from } 7.8 \% \text { to }<6.5 \%\end{array}$ & No SAR reported \\
\hline 6 & $\begin{array}{l}\text { Saslow et } \\
\text { al, United } \\
\text { States, PLOS } \\
\text { ONE, } 2014^{16}\end{array}$ & 44 & $\begin{array}{l}\text { Medium car- } \\
\text { bohydrate, } \\
\text { low fat, } \\
\text { calorie-re- } \\
\text { stricted, car- } \\
\text { bohydrate } \\
\text { counting } \\
\text { diet (MCCR) } \\
\text { ( } n=18) \\
\text { or LCKD, } \\
\text { noncalorie- } \\
\text { restricted } \\
\text { diet }(n=16) \\
\text { for } 3 \text { mo }\end{array}$ & $\begin{array}{l}\text { Mean HbA1c level was unchanged from } \\
\text { baseline in the MCCR diet group, while } \\
\text { it decreased by } 0.6 \% \text { in the LCK group. } \\
\text { Forty-four percent of the LCK group } \\
\text { discontinued one or more diabetes } \\
\text { medications, compared with } 11 \% \text { of the } \\
\text { MCCR group }(p=0.03)\end{array}$ & $\begin{array}{l}\text { No serious adverse effects } \\
\text { reports }\end{array}$ \\
\hline
\end{tabular}

Abbreviation: SAR, serious adverse reaction. 
modality in the treatment of diabetes. This involves inducing a fuel switch from a dysfunctional carbohydrate metabolism to fat metabolism, for which necessary molecular mechanisms are already present in the human biological ecosystem. However, expertise and consensus on nutrition and medicinal protocol need to be developed and standardized to apply this approach on population in general.

\section{References}

1 Unnikrishnan R, Anjana RM, Deepa M, et al; ICMR-INDIAB Collaborative Study Group. Glycemic control among individuals with self-reported diabetes in India-the ICMR-INDIAB Study. Diabetes Technol Ther 2014;16(9):596-603

2 Expert Panel on Detection, Evaluation, and Treatment of High Blood Cholesterol in Adults. Executive summary of the third report of the National Cholesterol Education Program (NCEP) expert panel on detection, evaluation, and treatment of high blood cholesterol in adults (adult treatment panel III). JAMA 2001;285(19):2486-2497

3 Dietary guidelines for Indians-a manual. Available at: http:// ninindia.org/DietaryGuidelinesforNINwebsite.pdf. Accessed October 1, 2018.

4 Serra-Majem L, Bes-Rastrollo M, Román-Viñas B, Pfrimer K, Sánchez-Villegas A, Martínez-González MA. Dietary patterns and nutritional adequacy in a Mediterranean country. $\mathrm{Br} \mathrm{J}$ Nutr 2009;101(Suppl 2):S21-S28

5 Kuipers RS, Luxwolda MF, Dijck-Brouwer DA, et al. Estimated macronutrient and fatty acid intakes from an East African Paleolithic diet. Br J Nutr 2010;104(11):1666-1687

6 Paoli A, Rubini A, Volek JS, Grimaldi KA. Beyond weight loss: a review of the therapeutic uses of very-low-carbohydrate (ketogenic) diets. Eur J Clin Nutr 2013;67(8):789-796

7 Lean ME, Leslie WS, Barnes AC, et al. Primary care-led weight management for remission of type 2 diabetes (DiRECT): an open-label, cluster-randomised trial. Lancet 2018;391(10120): 541-551

8 Uusitupa M. Remission of type 2 diabetes: mission not impossible. Lancet 2018;39110120:515-516
9 Ludwig DS, Hu FB, Tappy L, Brand-Miller J. Dietary carbohydrates: role of quality and quantity in chronic disease. BM] 2018;361:k2340

10 Manyam BV. Food, dietetics and nutrition in ancient India. Bull Indian Inst Hist Med Hyderabad 1995;25(1)(2):79-99

11 Yancy WS, Foy M, Chalecki AM, Vernon MC, Westman EC. A low-carbohydrate, ketogenic diet to treat type 2 diabetes. Nutr Metab (Lond) 2005;2:34

12 Westman EC, Yancy WS, Mavropoulos JC, Marquart M, McDuffie JR. The effect of a low-carbohydrate, ketogenic diet versus a low-glycemic index diet on glycemic control in type 2 diabetes mellitus. Nutr Metab (Lond) 2008;5:36

13 Davis NJ, Tomuta N, Schechter C, et al. Comparative study of the effects of a 1-year dietary intervention of a low-carbohydrate diet versus a low-fat diet on weight and glycemic control in type 2 diabetes. Diabetes Care 2009;32(7):1147-1152

14 Saslow LR, Mason AE, Kim S, et al. An online intervention comparing a very low-carbohydrate ketogenic diet and lifestyle recommendations versus a plate method diet in overweight individuals with type 2 diabetes: a randomized controlled trial. J Med Internet Res 2017;19(2):e36

15 Hussain TA, Mathew TC, Dashti AA, Asfar S, Al-Zaid N, Dashti HM. Effect of low-calorie versus low-carbohydrate ketogenic diet in type 2 diabetes. Nutrition 2012;28(10):1016-1021

16 Saslow LR, Kim S, Daubenmier JJ, et al. A randomized pilot trial of a moderate carbohydrate diet compared to a very low carbohydrate diet in overweight or obese individuals with type 2 diabetes mellitus or prediabetes. PLoS One 2014;9(4):e91027

17 Hallberg SJ, McKenzie AL, Williams PT, et al. Effectiveness and safety of a novel care model for the management of type 2 diabetes at 1 year: an open-label, non-randomized, controlled study. Diabetes Ther 2018;9(2):583-612

18 Bhanpuri NH, Hallberg SJ, Williams PT, et al. Cardiovascular disease risk factor responses to a type 2 diabetes care model including nutritional ketosis at one year: an open label, non-randomized, controlled study. Cardiovasc Diabetol 2018;17:56 